\title{
NATURE TOURISM PLANNING USING RIVER-BASED RESOURCES AND RECREATIONAL ASSESSMENT FOR SUNGAI DINDING, PERAK, MALAYSIA
}

\author{
${ }^{1,3}$ Ahmad Ainuddin Nuruddin and ${ }^{2}$ Ali Muhammad Ali \\ ${ }^{1}$ Institute of Tropical Forestry and Forest Products (INTROP), \\ Putra Infoport, Universiti Putra Malaysia, 43400 UPM, Serdang, Selangor DE, Malaysia \\ ${ }^{2}$ Perhilitan, KM 10. Jln Cheras, 561000, Kuala Lumpur, Malaysia \\ ${ }^{3}$ Faculty of Forestry, Universiti Putra Malaysia, 43400 UPM, Serdang, Selangor, Malaysia
}

Received 2013-09-19; Revised 2013-11-05; Accepted 2014-01-04

\begin{abstract}
Rivers and stream corridors provide a variety of valuable resources including aquatic habitats for fish and other organism, riparian habitats for fish and other organism, riparian habitats for vegetation and terrestrial wildlife. They also provide potential recreational and nature tourism activities. In order to fully identify potential recreational and activities, assessment of recreation resource element should be carried out. The objective of this study was to plan for nature tourism activities using river-based resources and recreational assessment of Sungai Dinding, Manjung, Perak. Uniqueness ratio of each zone for was measured along a $7 \mathrm{~km}$ stretch of Sungai Dinding. The highest uniqueness ratio value was Zone 5 with the total value of 13.20. Zone 3 and 1 ranked the second and third respectively with the total value of 9.59 and 8.79. In the physical and chemical category, Zone 5 has the highest score with the value of 6.23 . The highest uniqueness value scored in this area is the width of the river during low flow and bank height. Several recreational and nature tourism activities were suggested as a result of the assessment. Building of facilities such as jetties and fishing docks are proposed to enhance recreational experience to the people who want to enjoy the many activities in Sungai Dinding. This approach helps natural resource managers to plan for nature tourism activities.
\end{abstract}

Keywords: River Assessment, Recreation, Water, Mangrove, Riparian

\section{INTRODUCTION}

Rivers and streams play a vital role in economic development of a country by providing sustainable water resources (Zeitoun et al., 2013) and also an important transportation route for goods and services (Kusky, 2009). These transportation route enable access to remote areas where roads are unavailable due to rough terrain and remoteness. Many of the world's important ports are located at the rivers' mouth and have developed into world class cities that served as important commercial centres and major transportation hubs (Chang, 2012).

Rivers and stream corridors provide important riparian habitats for terrestrial wildlife and also aquatic habitats for fish and other aquatic organisms (Nilsson and Svedmark, 2002). They are also important places for hydrophytes which thrive in wet soils and occasional flooding. These plants are also source for the organic matter and detritus that the serve as food for the aquatic fauna (Halls, 1996).

Rivers and streams contain water which has important relationship with human as a recreational resources with many types of recreation activities such as swimming to kayaking. Rivers and its surrounding provide several valuable natural and aesthetic sites for cultural, historical (May, 2006) and physical attributes for the purpose of recreational users. Rivers in urban areas are also perceived as urban greenways providing

Corresponding Author: Ahmad Ainuddin Nuruddin, Institute of Tropical Forestry and Forest Products (INTROP), Putra Infoport, Universiti Putra Malaysia, 43400 UPM, Serdang, Selangor DE, Malaysia 
recreation and aesthetics experiences (Gobster and Westphal, 2004). Users are willing to pay for using these water-based recreational sites. Stream course also provide "recreation habitat" for water dependent activities such as boating and fishing, as well as waterenhanced activities such as camping and bird watching (Shelby et al., 1992).

In order to identify potential sites for instream activities, rivers need to be assessed for potential recreational and nature activities. There are many methods of evaluating the potential of river for recreational activities (Miskell, 2009). Craighead Assessment Method is proposed Craighead and Craighead (1962) where this evaluation system considers the river potential for three activities; boating, hunting and fishing. Rating is based on 12 variables for boating and hunting and 13 variables for fishing. The score possible for each variable ranges from 0 to a maximum of 3, 4 or 5 depending on the variable. Score are then summed and the totals used to indicate a river's comparative suitability for the type of recreation.

The second method is Dearinger et al. (1968) which proposed the evaluation method, which consists of two steps: First, the stream was rated for 92 natural and cultural variables and second, these ratings were used to develop scores for each of 16 recreation activities. Only the rating values for appropriate variables were used in developing each activity score, each rating value being multiplied by a weight based on the relative significant of the variable to the activity. The comparative suitability of each stream for an activity was then calculated by expressing the total score as a percentage of the total possible score.

River Inventory and Variable Evaluation for Recreation Suitability (RIVERS) is another method to evaluate rivers for recreation potentials. This method has 5 basic features: Its evaluates river environments for 16 different recreational activities; evaluation involves a broad range of pertinent natural and cultural variables; it is applicable to rivers of all types from remote to highly urbanized areas; computer programs are used in computations and; it permits quantitative comparisons between rivers of various types or between segments of the same river or different rivers (Chubb and Baumann, 1976). Riverscape Assessment Method was proposed by Leopold and Marchand (1968). Three groups of factors were evaluated; physical factors including valley topography, river width and water velocity; biological factors which include surrounding vegetation, animals in the area, flora and fauna of the area; human use and interest factors include land use, accessibility and historical sites. The final evaluation of recreation potential was made in terms of unique ratio

All the above methods attempt to objectively evaluate the potential of a river landscape and related activities. However, Craighead Assessment Method, Dearinger Assessment Method, River Inventory and Variable Evaluation for Recreation Suitability (RIVERS) Assessment Method are not suitable to be used in obtaining needed data on every selected zone for further recreation opportunity inventory. The objective of this study was to plan for nature tourism activities using river-based resources and recreational assessment of Sungai Dinding, Manjung and Perak.

\section{MATERIALS AND METHODS}

\subsection{Study Area}

This study was conducted in Sungai Dinding which is located in one the most develop district in Perak state. The district of Manjong formerly known as Dinding district has a total area of $1,168 \mathrm{~km}$ square with estimated population of 175,194 . Situated on the west side of Perak state, this district borders with Larut Matang and Kuala Kangsar district on the north, district of Perak Tengah on the east and district of Hilir Perak on the south side. This district is well known as tourist attraction area with several attractive recreation areas such as Teluk Batik, Pasir Bogak, Coral Bay, Teluk Nipah, Teluk Rubiah and Pantai Pasir Panjang. Because of natural attractive coastal area, these areas are also known as "Manjong Permai" Wikipedia, 2010. Sungai Dinding which has a length of estimated $20 \mathrm{~km}$, is the longest river in District of Manjung.

\subsection{Methods}

A stretch, which started from Kampong Gajah Mati $\left(04^{\circ} 16.00^{\prime} \mathrm{N}\right.$; $\left.100^{\circ} 39.70^{\prime} \mathrm{E}\right)$ to Sungai Gapis estuary $\left(04^{\circ} 19.85^{\prime} \mathrm{N}\right.$; $\left.100^{\circ} 39.90^{\prime} \mathrm{E}\right)$, estimated about $7 \mathrm{~km}$ along a coastline was chosen. One of the rationales for choosing this particular stretch is because of the highly development of the area in industrialization and recreation in part of the stretch of the river.

This study was divided into four stages:

- Reconnaissance survey and observation along the river stretch

- Leopold Riverscape Assessment

- Recreation resource site inventory

- Proposing recreation activities 
Using information available on the area, a method of assessment was selected to identify a most unique area within the stretch using several listed technique. Site inventory was conducted to evaluate the available resources of the area and several mathematical calculations were used to measure the strength of the resources. Lastly, several recreation activities were proposed together with recreation facilities to several selected sites of the zones.

The purpose of reconnaissance survey and observation along the river stretch is to get a brief idea of the study area and obtained valuable information about the area. Topography map of Lumut (Series 7010; Sheet 63 ) and photo shot on several interesting location a long a river were used to determine the zoning stretch for evaluation. Several informal interviews with locals and residents and direct observation gave more adequate and valuable information mostly on interesting places and presence of several rare species of flora and fauna within the area. All these information are valuable for proposing recreational opportunities and facilities.

The river was divided into segments of $1 \mathrm{~km}$, measured along the centerline of the river. A large amount of information about each segment of rivers and land were collected before going to sites using topography maps, photos and other sources. Corridors of up to $200 \mathrm{~m}$ on each side of the river were also evaluated. The seven zones were measured and observed according to the Leopold Riverscape Assessment Method where three groups of factors were considered; physical and chemical factors, biological factors and human use and cultural factors.

Assessments of physical and chemical factors were done during the low flows. The qualities and characteristic of flora and fauna on both riverine and land were visually assessed along the banks. Human use and cultural factors were assessed according to current impacts and projection of future impact caused by human presence.

\subsection{Site Recreation Resource Inventory}

After considering the value of unique value ratio obtained from Leopold Riverscape Assessment, only two zones with the highest unique ratio were inventoried for more information on the resource for both areas. The choice of taking only two zones were made to create less impact to the natural resources and the environment because the more area inventoried, the more impact environment to the area will occurs. Also, the choice will allow a comparison study and activity compatibility analysis.

An inventory base line was aligned in each zone on both side of the river along the riverbank. Inventory spot was set up along the riverbank to the other end of each zone. Total inventory spots were 40 spots with $50 \mathrm{~m}$ apart from each spot in each the zone. For each spot, observation and inventory were carried out where a radius of $25 \mathrm{~m}$ in each side of the spot was measured (Fig. 1). Visual distance from shoreline was estimated 25 $\mathrm{m}$. Collection of data included physical river features on both sides of the river zones.

Recreation inventory assessment compromised of four categories: Hydrology, geographical and physical characteristics, vegetation and wildlife. The point rating was used where each variables is rated according to a 4 point likert scale given from 1-4, that is the rating 1Very not attractive, 2-Not attractive, 3-Attractive and 4Very attractive.

\subsection{Proposing Recreation Activities}

Several activities were proposed according to the recreational resource available from the inventory process. Each of the activity proposed were assessed according to the criteria determined.

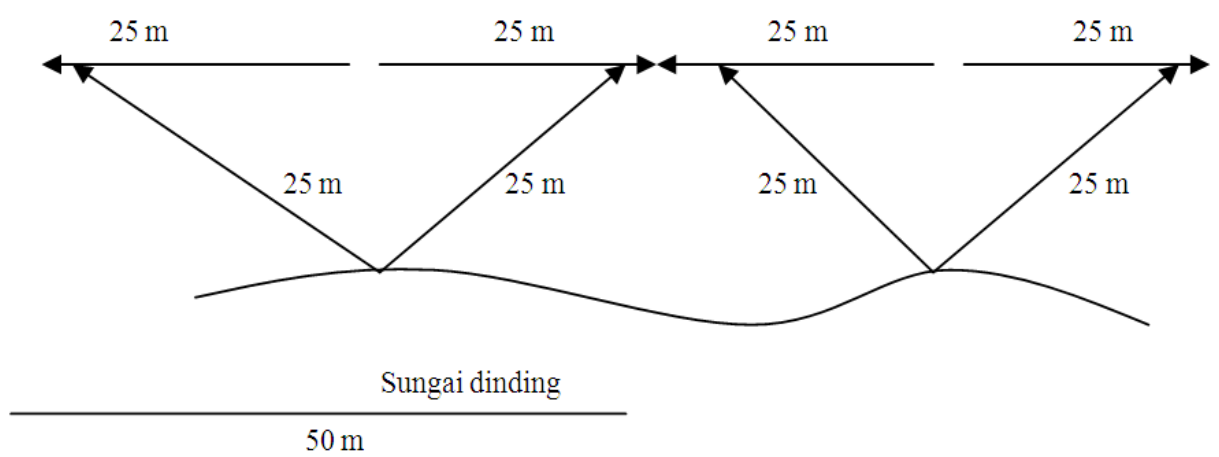

Fig. 1. Area of one zone 
These criteria determinations for activity were made to identify suitable activities to be developed according to the strength of the resources of each area inventoried.

Suitable recreation facilities, which can enhance users recreation experience, are important to be developed. The listed facilities for each zone must be compatible according to suggested recreation activities for the particular zones. The important of these facilities is to create comfort activity zones to the recreational users. Proper situated facilities can avoid conflicts among users in the area and will give less negative impact to the environment.

\section{RESULTS}

\subsection{Zonal Recreation Resources Value}

A summary of the uniqueness ratio of each zone for each measured parameter along $7 \mathrm{~km}$ stretch of Sungai Dinding. The highest uniqueness ratio value is Zone 5 with the total value of 13.20 . Zone 3 and 1 ranked the second and third respectively with the total value of 9.59 and 8.79 .

In the physical and chemical category, Zone 5 has the highest score with the value of 6.23. The highest uniqueness value scored in this area is the width of the river during low flow and bank height. This zone has a poor score in biological category where it ranked fourth after Zone 3, 7 and 1. In the category of human use and interest, Zone 5 ranked the highest among all zones measured in the same category. The highest score obtained was due to the presence of trash and litter and degree of degradation in the area.

Zone 3, which ranked the second, has a highest uniqueness ratio value in biological category measured but quite lower score in the other two categories. Zone 1, 7, 42 and 6 are in the third, fourth, fifth, sixth and seven respectively (Fig. 2).

\subsection{Existing Recreation Activity and Facilities}

The potential of this river to serve the needs of recreation experience have been manipulated by several group of user in several ways. Several water-based activities such as fishing, kayaking, boating and yachting are part of existing recreation activities that are mainly done by the users to the area but these activities are not fully develop to enhance high quality recreation experience to the users.

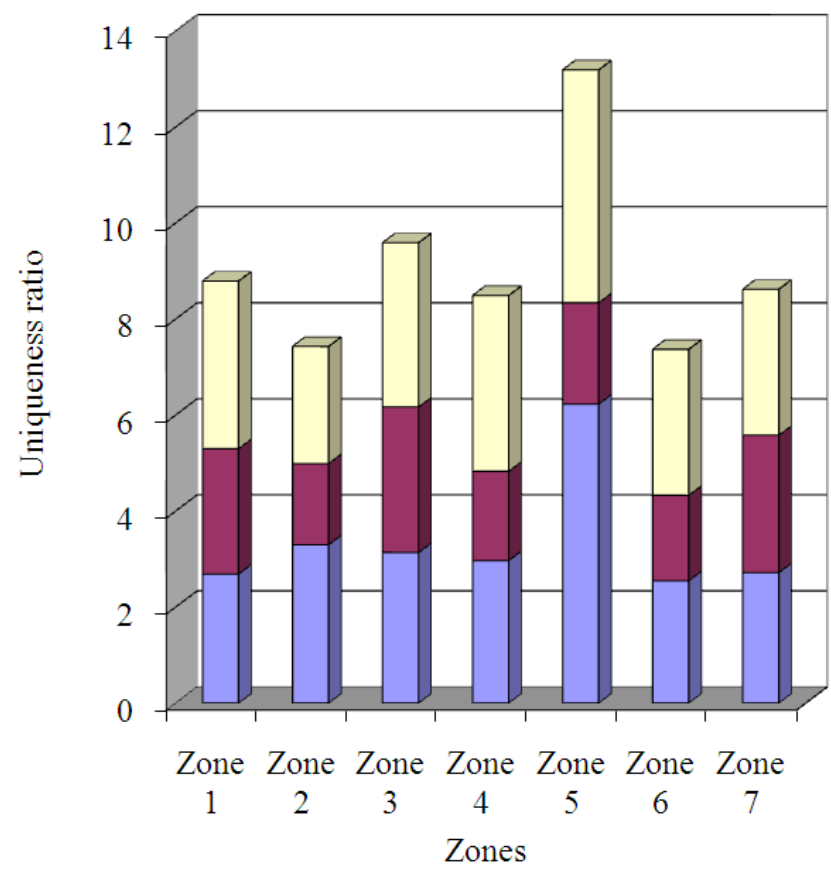

口Physical and chemical characteristic $\mathbf{\square}$ Biological character $\mathbf{\square}$ Human use and interest

Fig. 2. Uniqueness ratio between zones 
Besides activities available to the area, recreation facilities are also important factors that influence people to participate in recreation activities in the area. Facilities on the area include several gazebo in Kampong Baharu and the most interactive recreation structure are in Kampong Nenas where a new chalet was develop for the use of the villagers and other recreation users in the area.

\subsection{Existing Recreation Resource in Selected Zones}

The following Table 1 shows the synthesis of collection of data from selected sites. The means value is taken as the mean value for every spot for each criterion measured during observation.

\subsection{Hydrology}

Both zones show a higher mean value in this category observed compared to other category measured. Zone 3 shows a higher mean value in almost every criteria measured except in water flows features compare to Zone 5 (Table 1). The highest value score in Zone 3 is in natural disturbance of the area while for Zone 5 is the suitability of the zone for activities. The lowest measurement in both zones is on odor features.

Both sides of Zone 3 are mangroves area where it limits most development activities of the area. Human disturbance mostly on rubber and oil palm plantation in Kampong Batu Undan but the degree of disturbance are limited. In Zone 5, the water flows measured in this area shows the highest score due to river intersection between the main river of Sungai Manjung and Sungai Air Tawar.

\subsection{Geographical and Physical Characteristic}

Table 2 shows the geographical and physical characteristics score for Sungai Dinding. Zones 3 score a higher average mean value in attractiveness of geographical features, bank stability, soil fertility and permeable of the soil compared to Zone 5 . Zone 5 scores higher value in intactness of the area in human development, soil stability, visibility and width of mud flats compared to Zone 3. One of the attractive features in Zone 5 is the existence of the rocky area in several part of the spot observed and this is suitable for certain activities.

\subsection{Vegetation}

Zone 5 shows the higher mean value compared to Zone 3 (Table 3). This category ranked third in both zones among the entire category measured. Vegetation pattern in Zone 3 shows a highest measurement while in Zone 5 the density of the forest score highest. The lowest score in both zones are on shrubs and ferns features where mangroves limited the growth of this species in the area.

In evaluating species diversity, two types of growth are observed. The mangrove species observed in both area mostly are non-dipterocarp species such as Perepat (Sonneratia alba), Bakau Kurap (Rhizophora mucronata), Bakau Minyak (Rhizophora apiculata) Lenggadai (Bruguiera parviflora), Api-api (Avicennia sp.), Berus (Bruguiera cylindrical) and Nyireh (Xylocarpus sp.) which are common species in the area.

Table 1. Mean values for hydrology

\begin{tabular}{lll}
\hline Hydrology & Zone 3 & Zone 5 \\
\hline Views of the river & 3.60 & 3.40 \\
Water flows & 3.60 & 3.40 \\
Water resources status & 3.50 & 3.55 \\
Water quality & 3.55 & 3.52 \\
Color & 3.57 & 3.50 \\
Odor & 3.47 & 3.25 \\
Disturbance (human activities) & 3.52 & 3.47 \\
Natural disturbance & 3.85 & 3.52 \\
Suitability for activities & 3.75 & 3.72 \\
Mean & 3.60 & 3.48 \\
\hline
\end{tabular}

Table 2. Mean values for geographical and physical characteristics

\begin{tabular}{lll}
\hline $\begin{array}{l}\text { Geographical and } \\
\text { physical characteristics }\end{array}$ & Zone 3 & Zone 5 \\
\hline Intactness of a viewscape & 3.65 & 3.55 \\
Shoreline soil & 3.20 & 1.35 \\
Attractiveness of Riverscape features & 3.50 & 3.35 \\
Slope gradient & 3.30 & 3.20 \\
Visibility & 3.50 & 1.55 \\
Width of mud flats & 3.10 & 3.25 \\
Mean & 3.38 & 2.71 \\
\hline
\end{tabular}

Table 3. Mean values for vegetation

\begin{tabular}{lll}
\hline Flora & Zone 3 & Zone 5 \\
\hline Views of flora & 3.55 & 3.40 \\
Mangroves trees variety & 3.42 & 3.30 \\
Forest trees variety & 2.02 & 2.90 \\
Shrubs and ferns & 1.48 & 1.93 \\
Vegetation pattern & 3.62 & 3.77 \\
Density & 3.55 & 3.50 \\
Upperstorey & 3.18 & 3.42 \\
Under storey & 3.40 & 3.27 \\
Ground cover & 2.35 & 2.30 \\
Disturbance (human activities) & 3.13 & 3.37 \\
Natural disturbance & 3.57 & 3.40 \\
Mean & 3.02 & 3.14 \\
\hline
\end{tabular}


Several dipterocarp trees were also observed mostly in Zone 4 are Chengal Batu (Hopea semicuneta), Meranti Paya (Shorea uliginosa), Resak Ranting Kesat (Vatica odorata) and several forest species. One of the interesting species in the area are Balau Puteh also known as Damar Laut (Shorea lumutensis) which are known endemic to this area.

\subsection{Wildlife}

Sighting of mammals, birds and amphibians are rather low in both zones (Table 4). Both zones shows very poor mean values of fauna which sighting and signs of fauna in both zones are rather unattractive for activity proposed. Several mammals species especially Longtailed Macaque (Macaca fascicularis) are the dominant species even though during visual inventory only several spot this mammals can be observed but the group of observation consists of at minimal count of 5 animals per group. Dusky leaf Monkey (Presbytis obscurus) is also primate species that can be observed mostly in Zone 5 but not as many as Long-tailed macaques. Other mammals species such as small-clawed Otter (Aonyx cinerea) and Smooth Otter (Lutra perspicillatus) are other mammals which present in the area but it is difficult for sightings, only footprint signs on mudflats during low tides.

For birds' species, several species were observed mostly during low tides. Birds such as Grey Heron (Ardea cinerea), White bellied Sea-Eagle (Haliaeetus leucogaster), Common Redshank (Triga tetanus), Common Kingfisher (Alcedo atthis), Mangrove Pitta (Pitta megarhyncha) and Mangrove Blue Flycatcher (Cyornis rufigastra) are common species in the area. In terms of amphibians, the only species that are considered as resident species for the area Water Monitor (Varanus salvator).

\subsection{Setting Proposed Recreation Activities}

According to one of the policy stated in the District of Manjung Development Plan for the year 1991-2010, considering sustaining the eco-tourism resources should make total development for tourist potential. A list of three recreation activities is proposed based on mean values and objective settings. A set of criteria required for each activity are also listed and a selection of suitable activities were based on the highest mean value obtained from the evaluation. These proposed activities are selected based on two types of activities that are suitable to the area; namely water-dependent and water-enhanced activities. The mean values and objective setting before are also taken consideration for the proposal of suitable activities for the area.

Two types of water-dependent activities are kayaking and fishing while for water-enhance activities are nature study. A set of criteria required for each activity is also listed and selections of suitable activities were being based on the highest mean value obtained from the evaluation (Table 5).

Table 4. Mean values for wildlife

\begin{tabular}{lll}
\hline Fauna & Zone 3 & Zone 5 \\
\hline Sightings of mammals & 2.10 & 2.32 \\
Sightings of birds & 1.90 & 2.15 \\
Sightings of Amphibians/Reptiles & 1.40 & 1.24 \\
Sign of mammals & 1.60 & 1.80 \\
Sign of birds & 1.20 & 1.25 \\
Sign of amphibians/reptiles & 1.30 & 1.27 \\
Mean & 1.58 & 1.67 \\
\hline
\end{tabular}

Table 5. Proposed activities and criteria requirement for each activity

\begin{tabular}{|c|c|c|}
\hline Activity & Description of activity & Criteria required \\
\hline 1. Nature study & $\begin{array}{l}\text { Water-enhance activity. } \\
\text { Provide opportunities to } \\
\text { observed and appreciate } \\
\text { the natural settings of the } \\
\text { environment, diversity and } \\
\text { human and natural effect to } \\
\text { the surroundings and the } \\
\text { ecological changes of the ecosystem. }\end{array}$ & $\begin{array}{l}\text { View of flora } \\
\text { Mangroves trees variety } \\
\text { Vegetation pattern } \\
\text { Disturbances (Human) } \\
\text { Natural disturbance } \\
\text { Intactness of Viewscape }\end{array}$ \\
\hline 2. Kayaking & $\begin{array}{l}\text { Water-dependent activity. } \\
\text { Provide opportunities by } \\
\text { means to access the } \\
\text { water ways and viewing } \\
\text { the landscape. }\end{array}$ & $\begin{array}{l}\text { Attractiveness of Riverscape } \\
\text { Views of the river } \\
\text { Water status } \\
\text { Water quality } \\
\text { Water flows } \\
\text { Suitability for activities }\end{array}$ \\
\hline 3. Fishing & $\begin{array}{l}\text { Water-dependent activity. } \\
\text { Provide opportunities to access to waterways, } \\
\text { harvesting and/or viewing sport fishing activities. }\end{array}$ & $\begin{array}{l}\text { Water flows } \\
\text { Water quality } \\
\text { Suitability for activities }\end{array}$ \\
\hline
\end{tabular}


Table 6. Weighted score among zones

\begin{tabular}{|c|c|c|c|c|c|}
\hline \multirow[b]{2}{*}{ Activities } & \multirow[b]{2}{*}{ Criteria settings } & \multicolumn{2}{|l|}{ Zone 3} & \multicolumn{2}{|l|}{ Zone 5} \\
\hline & & Weighted score & Score & Weighted score & Score \\
\hline Nature & Views of flora & 1.5 & 61.2 & 1.40 & 54.8 \\
\hline \multirow[t]{6}{*}{ Study } & Mangroves trees variety & 1.4 & 57.2 & 0.80 & 31.2 \\
\hline & Vegetation pattern & 1.5 & 58.8 & 2.00 & 70.0 \\
\hline & Human disturbance & 0.9 & 37.2 & 1.25 & 50.0 \\
\hline & Natural disturbance & 1.6 & 62.8 & 1.40 & 55.2 \\
\hline & Intactness of viewscape & 1.1 & 38.4 & 1.50 & 60.0 \\
\hline & Mean value & 1.4 & 52.6 & 1.40 & 53.5 \\
\hline \multirow[t]{7}{*}{ Kayaking } & Attractiveness Riverscape & 1.7 & 68.0 & 1.60 & 64.0 \\
\hline & Views of the river & 1.6 & 64.0 & 1.40 & 56.0 \\
\hline & Water resources status & 1.6 & 64.0 & 1.40 & 56.0 \\
\hline & Water quality & 1.6 & 62.0 & 1.50 & 61.2 \\
\hline & Water flows & 1.5 & 60.0 & 1.60 & 62.0 \\
\hline & Suitability for activities & 1.8 & 70.0 & 1.70 & 69.2 \\
\hline & Mean Value & 1.6 & 64.6 & 1.50 & 61.4 \\
\hline \multirow[t]{3}{*}{ Fishing } & Water flows & 1.5 & 60.0 & 1.60 & 62.0 \\
\hline & Water quality & 1.6 & 62.0 & 1.50 & 61.2 \\
\hline & Suitability for activities & 1.8 & 70.0 & 1.70 & 69.2 \\
\hline
\end{tabular}

\subsection{Evaluation of Recreation Potential for Proposed Activities}

The aim of this evaluation is to find out which activity is the most suitable for each zone where each zone have its own special characteristic for certain activities.

In estimating the recreation potential, generalized geographic or environment variables were used and weighting procedure for relating these variable recreation potential were used. In the Chubb and Bauman (1976) Method, the equivalent number is supplied by the classification system used, in which place in the classification corresponds it number. For the purpose of this study, a weighted method is used to estimate the recreation potential for each recreation activities proposed according to criteria settings.

Table 6 summarized the analysis done for Zone 3 and 5 based on criteria determined for each activity and the strength of the resources according to each category measured. In Zone 3, the highest score according to criteria setting measured for each activity are kayaking with the score of 64.6 followed by fishing (64.0) and nature study (52.6). In Zone 5, fishing activity ranked first among all activities measured with total score value of 64.1, followed by kayaking (61.4) and nature study (53.5).

\subsection{Selection of Proposed Activities}

From the list of three activities suggested for each zones, only one activity was selected for each zone. The two selected activities were kayaking in Zone 3 while fishing in Zone 5. Both activities shows higher mean value for each criteria setting for each activities and the weighted score obtained shows the potential of the resources available appropriate with the activity proposed.

The reason for proposing only one activity for each area is to avoid conflict and to low the environment impact to the area. Suggestion on additional activities must be based on suitability of the activity to the mangrove environment that limits most water-dependent and water-enhanced activities.

Figure 3 shows the difference mean value between each proposed activities in Zone 3 and 5. For kayaking activity in Zone 3, the chart shows a slight different between these activities with nature study activity. In Zone 5, fishing activity shows the almost same situation with kayaking. Generally, we can say that both activities are related with each other in this area.

To enrich the recreation experience among users to both areas, several recreation facilities are suggested. These facilities are suggested to be located at different location to avoid conflict of area use among users and to reduce impact to the environment. For the purpose of kayaking activity in Zone 3, several jetties are needed for the use of launched kayak. For the purpose of this activity also, zoning buoys are also needed as to direct user of the area for this activity.

Several supporting facilities are also purpose to enhance recreation experience among participant. Besides constructing jetties as a starting point for this activity, a gazebo is needed as waiting sites for participant for this activity and to give users opportunity to view the surroundings. 


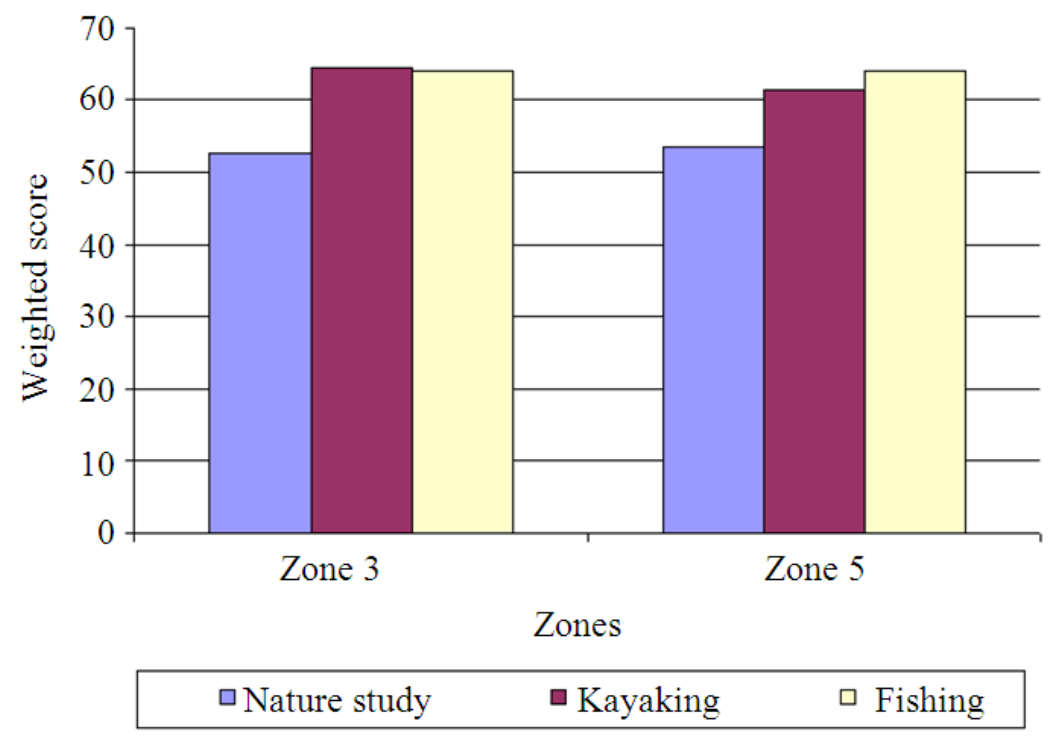

Fig. 3. Weighted score between proposed activities in selected zones

Fishing activity need fishing dock boating logistical facility and access to the river. Information about the potential fishing sites and types of game fish available in the area is needed before constructing these facilities for the users.

\section{DISCUSSION}

The objective of this paper was to plan for nature tourism activities using river-based resources and recreational assessment of Sungai Dinding, Manjung, Perak. This approach evaluates available resources in and near the river vicinity where seven zones were measured and observed according to the Leopold Riverscape Assessment Method. Three groups of factors were considered; physical and chemical factors, biological factors and human use and cultural factors.

Two zone, Zones 3 and 5 with the highest unique ratio were selected and inventoried for recreation inventory assessment. This approach allows quantitative assessment based on the factors discussed above and provide authority with data to support proposed nature tourism activities and building of related infrastructures to enhanced nature tourism activities.

Kayaking is one of the proposed nature tourism activities in Sungai Dinding. Kayaking is suitable due to relatively calm water of Sungai Dinding and can be done individually of in groups. Kayaking also allows one to get closer to the wildlife in the river or at the banks of Sungai Dinding. It also suitable for exploring further smaller river that comes in into the Sungai Dinding. In order to improve kayaking experience among the users, guides should be equipped with well-maintained kayaks and trained in water safety. They should be able to provide first-aid to the tourist in the case of emergency.

Sungai Dinding has many varieties of fishes suitable for recreational fishing. The riparian mangrove growing by its banks serve as nursery and habitats for fishes, prawns and other marine fauna. Fishing can be done from many jetties located at Sungai Dinding or by using boats that can go to various fishing spots that are familiar with locals. There are also shellfish such as clams that are abundant in the mangrove forest and tourist can go clam picking and this activity can be packaged in the nature tourism activities.

This study provides a method in which river can be assessed and nature tourism activities can be proposed based on the assessment. It also helps to incorporate nature tourism activities in $\mathrm{Sg}$. Dinding river management planning. Many countries recognized the multiple-use of rivers and have incorporate nature tourism and recreational planning in the overall river and watershed management (Nilsson and Langaas, 2006).

The present study quantified recreational resources of Sg. Dinding and identified suitable recreational and nature tourism activities based on the assessment. However, the results of the assessment only applies to Sg. Dinding and can be modified to suit others rivers. This study does not have stakeholders' input and to be more inclusive, stakeholders dialogue should be 
undertaken. The consensus developed from the dialogue can be incorporated into the overall river management plan.

\section{CONCLUSION}

Sungai Dinding is the longest river in District of Manjung and this study showed that there many recreational activities that can be developed here. Among the most suitable activities based on the potential recreation assessment, kayaking in Zone 3 and fishing in Zone 5.

Kayaking in Zone 3 is a suitable activity to be developed due to the hydrological conditions of the river while Zone 5 provides a good recreational fishing activity mostly because of the presence of mangrove trees which provide a habitat that is suitable for the growth of several phytoplankton and micro algae which are important as food sources for the growth of certain species of fishes and other aquatic life. Building of facilities such as jetties and fishing docks are proposed to enhance recreational experience to the people who want to enjoy the many activities in Sungai Dinding.

This study is able to demonstrate that river characteristics and attributes assessment can be used to estimate the recreation potential for each recreation activities proposed according to criteria developed. Thus river managers and nature tourism planner can use this approach for better planning.

\section{REFERENCES}

Chang, M.T., 2012. Forest Hydrology: An Introduction to Water and Forests. 3rd Edn., CRC Press, ISBN10: 143987994X, pp: 595.

Chubb, M. and E.H. Baumann, 1976. The RIVERS method: A pilot study of river recreation potential assessment. 1st Edn., Department of Geography, Michigan State University, pp: 76.

Craighead, F.C., Jr. and J.J. Craighead, 1962. Recreational classification, inventory and evaluation. Naturalist, 13: 19-19.

Dearinger, J.A., K. Harper and L.D. James, 1968. Esthetic and Recreational Potential of Small Naturalistic Streams Near Urban Areas. 1st Edn., University of Kentucky Water Resources Institute, Lexington, pp: 260.

Gobster, P.H. and L.M. Westphal, 2004. The human dimensions of urban greenways: Planning for recreation and related experiences. Landscape Urban Plann., 68: 147-165. DOI: 10.1016/S01692046(03)00162-2
Halls, A.J., 1996. Wetlands, Biodiversity and the Ramsar Convention: The Role of the Convention on Wetlands in the Conservation and Wise Use of Biodiversity. 1st Edn., Ramsar Convention Bureau, Gland, ISBN-10: 2940073228, pp: 166.

Kusky, T., 2009. The Role of Rivers and Floods in History and the Role of the Mississippi, Missouri and Illinois Rivers in the Development of the United States. In: Finding the Balance Between Floods, Flood Protection and River Navigation, Criss, R.E., Timothy M. Kusky, T.M. (Eds.), Saint Louis University, Center for Environmental Sciences, pp. $1-8$.

Leopold, L.B. and M.O. Marchand, 1968. On the quantitative inventory of the Riverscape. Water Resources Res., 4: 709-717. DOI: 10.1029/WR004i004p00709

May, R., 2006. "Connectivity" in urban rivers: Conflict and convergence between ecology and design. Technol. Soc., 28: 477-488. DOI: 10.1016/j.techsoc.2006.09.004

Miskell, B., 2009. Riverscape and flow assessment guidelines: Guidelines for the selection of methods to determine river flows based on landscape, natural character and visual amenity considerations. National Institute of Water and Atmospheric Research Ltd., pp: 75.

Nilsson, C. and M. Svedmark, 2002. Basic principles and ecological consequences of changing water regimes: Riparian plant communities. Environ. Manage., 30: 468-480. DOI: 10.1007/s00267-002-2735-2

Nilsson, S. and S. Langaas, 2006. International river basin management under the EU water framework directive: An assessment of cooperation and water quality in the baltic sea drainage basin. Ambio, 35: 304-311. PMID: 17240763

Shelby, B., C.T. Brown and J.C. Taylor, 1992. Streamflow and Recreation. 1st Edn., Department of Agriculture, Fort Collins, United States, pp: 27.

Zeitoun, M., Goulden, M. and D. Tickner, 2013. Current and future challenges facing transboundary river basin management. WIREs Clim Change, 4: 331349. DOI: $10.1002 /$ wcc. 228 